PERKAWINAN ADAT DALAM PERSPEKTIF UU 1974

\title{
PERKAWINAN ADAT SUNDA
}

SRI WAHYUNI ADE NINGSIH MEMED (2003051)

Email : srywahyuniade472@gmail.com 


\section{Latar Belakang}

Dalam hampir semua sistem budaya, upacara atau adat perkawinan menjadi salah satu bagian tersendiri yang dalam banyak hal, memiliki fungsi identitas atas budaya yang diwakilinya. Upacara perkawinan dalam konteks budaya merupakan salah satu tradisi yang bersifat ritualistik sebagaimana halnya aspek-aspek kehidupan lain dalam sistem kebudayaan tersebut. Prosesi yang dilakukan sebagai rangkaian upacara perkawinan tersebut biasanya menghadirkan sejumlah simbolsimbol budaya yang mewakili norma-norma budaya.

Perkawinan adalah peristiwa yang sangat penting, karena menyangkut tata nilai kehidupan manusia. Oleh karena itu perkawinan merupakan sebuah tugas suci (sakral) bagi manusia untuk mengembangkan keturunan yang baik dan berguna bagi masyarakat luas. Hal ini tersirat dan tersurat di dalam upacaraperkawinan. Semua kegiatan termasuk segala perlengkapan upacara adat merupakan lambang yang mempunyai makna dan pengharapan tertentu, yang bertujuan memohon kepada Tuhan Yang Maha Esa agar semua permohonan dapat dikabulkan.

\section{Metode Penelitian}

Metode penelitian ini menggunakan penelitian normatif empiris, yakni penelitian yang dilakukan dengan pendekatan pada norma atau subtansi hukum, dan perbandingan hukum. Penelitian hukum yang memadukan antara penelitian hukum normatif dan penelitian hukum sosial/empiris. Pada jenis penelitian semacam ini peneliti melakukan penelitian dengan mengkombain kedua tipe penelitian sebagaimana disebutkan diatas dalam 
penelitian. Pendekatan yang digunakan yakni pendekatan konseptualyangmerupakan pendekatan yang memberi sudut pandang analisa terhadap penyelesaian permasalahan dalam penelitian hukum, yang dilihat dari aspek dan konsep-konsep hukum yang melatarbelakanginya, bahkan bisa juga dilihat dari nilai-nilai yang terkandung dalam penormaan sebuah peraturan yang sekaitan dengan konsep-konsep yang digunakan. Penelitian yang dilakukan bersifat deskriptif analitis yaitu menggambarkan, menganalisis, menyimpulkan masalah-masalah yang menjadi objek penelitian.

\section{Analisis Dan Pembahasan perkawinan Adat sunda}

Perkawinan merupakan salah satu bentuk ibadah yang kesuciannya perlu dijaga oleh kedua belah pihak baik suami maupun istri. Perkawinan memiliki tujuan untuk membangun keluarga bahagia kekal dan abadi.

Adapun prinsip dasar masyarakat Sunda dalam perkawinan adalah senantiasa dilandasi oleh 3 sifat utama yakni silih asih, silih asuh, dan silih asah atau secara literal diartikan sebagai saling menyayangi, saling menjaga, saling mengajari. Ketiga sifat itu selalu tampak pada upacara adat sunda.

Berikut ini akan dikemukakan beberapa adat kebiasaan yang merujuk kepada adat perkawinan yang terdapat di daerah Jawa barat khususnya adat sunda:

\section{Rangkaian sebelum prosesi siraman}

\section{Nendeun Omong}

Keluarga calon pengantin pria berkunjung ke kediaman calon pengantin wanita dengan maksud mengutarakan niatnya untuk mempersunting wanita pilihannya. Biasanya pertemuan ini dilakukan secara informal.

\section{Narosan (Nyeureuhan)}

Ketika niat mempersunting wanita yang dipilih sudah diterima dengan baik, maka calon pengantin pria besama dengan keluarga kembali mengunjungi kediaman wanita secara formal. 


\section{Tunangan}

Berbeda dengan pertunangan pada umumnya, pertunangan di dalam adat sunda biasanya dilakukan dengan cara menukar kain yang dipakai untuk melilit perut setelah melahirkan. Hal tersebut menggambarkan adanya ikatan secara lahir dan batin dari kedua belah pihak.

\section{Seserahan}

Sebelum menuju acara pernikahan, calon pengantin pria akan membawa berbagai macam barang yang berupa kebutuhan calon mempelai wanita. Maksud dari memberikan seserahan tersebut adalah pihak pria yang memberikan bekal awal kepada calon mempelai wanita sebelum menjalani bahtera rumah tangga.

\section{Rangkaian prosesi siraman}

\section{Pengajian}

Prosesi siraman biasanya akan diawali oleh pengajian, hal itu bertujuan untuk membersihkan diri secara lahir dan batin.

\section{Ngecagkeun Aisan}

Calon pengantin wanita seolah digendong oleh kedua orang tua menggunakan kain samping gendongan. Setelah itu, ayah dari calon pengantin akan berjalan di depan dengan membawa sebuah lilin menuju tempat sungkeman, tahap ini memiliki makna bahwa jasa orang tua tidak ada batasnya. Selanjutnya, setelah sampai di area sungkeman, kain yang digunakan untuk menggendong calon pengantin akan dilepaskan, hal tersebut merupakan symbol lepasnya tanggung jawab orang tua dan memberikan rasa tanggung jawab tersebut kepada calon mempelai pria.

\section{Meuleum palika}

Meuleum palika atau bakar palika merupakan prosesi yang dilakukan dengan cara membakar 7 buah lilin yang menggambarkan sebuah pelita atau penerangan. Makna dari jumlah lilin tersebut adalah rukun iman dalam Islam dan jumlah hari dalam satu minggu. 


\section{Ngaras}

Calon mempelai membasuh kedua telapak kaki dan sujud atau sungkem kepada kedua orang tuanya. Hal tesebut melambangkan tanda bakti anak kepada orang tua yang sudah membesarkannya sekaligus meminta izin untuk menikah.

\section{Ngibakan (Siraman)}

Calon pengantin akan dimandikan oleh kedua orang tua atau oleh kerabat yang lebih tua yang telah berhasil membimbing mereka selama ini dengan menggunakan air yang terdiri dari campuran kembang tujuh rupa.

\section{Ngerik}

Prosesi memotong sedikit rambut calon mempelai wanita yang dilakukan oleh kedua orang tuanya. Hal tersebut bertujuan untuk mempercantik diri lahir dan batin.

\section{Ngeunyeuk Seuruh}

Ritual Ngeunyeuk Seureuh memiliki arti meramu sirih. Calon pengantin akan meminta restu kepada kedua orang tua mereka dan para orang tua pun akan memberikan nasihat mengenai kehidupan rumah tangga melalui berbagai benda yang dijadikan simbol.

\section{Rangkaian akad nikah}

\section{Mapag penganten}

Prosesi penyambutan pasangan pengantin bersama keluarga yang dipimpin oleh tokoh Mang Lengser.

\section{Ngabageakeun}

Ibu dari mempelai wanita mengalungkan bunga melati kepada mempelai pria yang kemudian diapit untuk masuk menuju pelaminan.

\section{Meuleum harupat}

Meuleum harupat atau membakar harupat merupakan prosesi pembakaran lidi yang berasal dari tulang rusuk daun kelapa. Kedua pengantin menyalakan dan 
memadamkan api secara bergantian. Hal tersebut adalah simbol bahwa kedua mempelai harus senantiasa bersama dalam menyelesaikan segala permasalahan.

\section{Muka panto}

Muka panto yang memiliki arti membuka pintu merupakan prosesi mengetuk pintu sebanyak tiga kali yang kemudian dilanjutkan dengan tanya jawab menggunakan pantun berbahasa Sunda. Hal ini memiliki arti datangnya warga baru di dalam rumah tersebut. Prosesi muka panto sering dijumpai di wilayah Banten.

\section{Nincak endog}

Nincak endog atau menginjak telur dilakukan oleh mempelai pria dan kemudian mempelai wanita akan mencuci kaki pasangannya dengan menggunakan air yang berasal dari kendi dan mengelapnya sampai kering. Hal tersebut melambangkan pengabdian seorang isteri kepada suami yang dimulai sejak hari itu.

\section{Huap lingkup}

Kedua pengantin disuapi oleh kedua orang tuanya masing-masing dan kemudian bergantian. Dimulai disuapi oleh para ibu dan kemudian dilanjutkan oleh para ayah. Setelah itu, kedua mempelai akan saling menyuapi melalui bahu masing-masing. Huap lingkup merupakan simbolis suapan terakhir yang diberikan oleh orang tua kepada anaknya dan menandakan bahwa kasih sayang kedua orang tua terhadap anak dan menantu sama besarnya.

\section{Pabetot bakakak hayam}

Dalam Bahasa Indonesia, pabetot bakakak hayam memiliki arti saling menarik ayam bakar. Pasangan suami istri saling duduk berhadapan dan memegang kedua paha ayam bakakak yang kemudian ayam tersebut akan ditarik hingga terbagi menjadi dua. Siapa yang mendapat bagian paling besar, harus membaginya dengan pasangan mereka melalui cara digigit bersama-sama. Hal tersebut menjadi tanda bahwa berapapun rezeki yang didapat harus dibagi dan dinikmati bersama. 


\section{Ngaleupaskeun japati}

Pengating masing-masing akan membawa burung merpati yang kemudian dilepaskan secara bersamaan. Hal tersebut menjadi simbolis bahwa peran orang tua sudah berakhir sejak hari itu karena kedua anak mereka telah mandiri dan memiliki keluarga sendiri.

\section{Saweran}

Pada prosesi saweran, kedua mempelai akan dihujani oleh koin, permen, dan beras. Koin dan beras merupakan arti dari kekayaan atau kemakmuran dan permen berarti manisnya hidup. Prosesi saweran akan diiringi oleh lantunan kidung yang mengandung nasihat bagaimana agar rumah tangga dapat berjalan dengan tentram dan makmur.

\section{Kesimpulan}

Masyarakat sunda memiliki karakteristik yang unik yang tercermin dari kebudayaan yang dimilikinya baik dari segi agama, bahasa, kesenian, adat istiadat, mata pencaharian, dan lain sebagainya. Tujuan Perkawinan merupakan sifat atau tabiat manusia yang cenderung untuk mengadakan hubungan sesama manusia. Allah Swt telah menjadikan hubungan perkawinan sebagai Sunnah para Rasul dimana ia akan melahirkan rasa saling cinta, sikap saling bekerjasama dengan kebaikan dan bantu membantu untuk mendidik keturunan. Melalui perkawinan juga, manusia akan dapat mengembangkan keturunan dan memenuhi ketenteraman jiwa karena perkawinan yang harmoni dan sesuai menurut tuntutan Ilahi sebagai tempat untuk bersehat jasmani maupun rohani. Perkawinan merupakan peristiwa bersejarah di mana ia tak mudah dilupakan bagi orang-orang beriman. Faktor yang menyebabkan masyarakat sunda masih mempertahankan tradisi ritual adat antara lain karena masyarakat Sunda mempunyai tingkat solidaritas yang sangat tinggi, seperti dalam setiap upacara mereka selalu saling membantu dan tolong menolong sehingga tradisi ini tidak luntur dan tetap dijalankan. Salah satu unsur budaya yang masih diakui keberadaannya dan dianggap sebagai warisan budaya yang penting dalam perjalanan hidup setiap orang adalah upacara perkawinan adat. Seperti upacara perkawinan adat Sunda khususnya dalam prosesi perkawinan adat terdapat 
kepercayaan dan keyakinan terhadap ritual perkawinan yang diwariskan para leluhur, jika secara esensial diwarnai dengan ajaran - ajaran Islam. Oleh karena itu, perkawinan merupakan perpaduan antara nilai adat istiadat masyarakat, ajaran agama dan undang - undang yang telah ditetapkan pemerintah Indonesia. Adapun prosesi upacaranya adalah sebagai berikut:

a)Tahap pra perkawinan; melamar, ngeuyeuk seureuh, dan seserahan, b)Tahap perkawinan; akad nikah dan sungkem, c)perkawinan, upacarasawer, nincak endog, muka panto, dan munjungan; banyak mengandung maksud, pesan dan harapan yang bermanfaat untuk kedua calon pengantin yang akan menjalani kehidupan berumahtangga.

\section{Daftar Pustaka}

Ahmad Azhar Basyir. 1999. Hukum Perkawinan Islam. Yogyakarta : UII Press. Heni Fajria Rif'ati dkk. 2002. Kampung Adat dan Rumah Adat di Jawa Barat. Dinas Kebudayaan dan Pariwisata Propinsi Jawa Barat. Hilman Hadi Kusuma. 1990. Hukum Perkawinan Adat. Bandung : Citra Aditya Bakti. Kamal Mukhtar. 1993. Asas - Asas Hukum Islam tentang Perkawinan. Jakarta : Bulan Bintang. Musa Asy'ari. 1992. Manusia Pembentuk Kebudayaan Dalam Al-Qur'an. Yogyakarta: LESFI.Prawirasuganda. 1964. Upacara Adat di Pasundan. Bandung : Sumur Bandung. Thomas Wiyasa Bratawidjaja. 1990. Upacara Perkawinan Adat Sunda. Jakarta : Pustaka Sinar Harapan. Wawancara dan observasi dengan Tokoh Agama, Tokoh Masyarakat/Budayawan, dan Anggota Masysrakat yang ada di beberapa desa di Jawa barat. 